\title{
Film education otherwise: A response to Bergala's dialectics of cinema and schooling
}

\author{
Alexis Gibbs* - University of Winchester, UK
}

\begin{abstract}
This paper engages with the question of whether education itself goes undervalued in Alain Bergala's The Cinema Hypothesis. Bergala identifies schools as being key in providing a space in which all young people should be able to access a cinema education, but in doing so situates the school simply as a means to the end of cinephilia. While this approach does much to nurture film appreciation via educational institutions, this paper argues there is insufficient justification for why schools should engage with film education to this end in a way that distinguishes it from other forms of art provision within current curricula. An alternative approach sees the school not just as a place for teaching film, but as a place in which perceptions of teaching, learning and schooling could also be transformed by the experience of film-viewing and criticism. In re-examining the four parts that Bergala prescribes for the role of schools in fostering programmes of film education, the paper questions whether his approach promotes film-as-art at the expense of school-as-education, and suggests that the two might have more to offer one another in classroom practice than their seeming opposition implies.
\end{abstract}

Keywords: film pedagogy; Bergala; film education; aesthetic education

Alain Bergala's contributions to exploring the place of film in formal education settings through The Cinema Hypothesis (published in English for the first time in 2016) and the Cinémathèque française's ongoing 'Cinéma, cent ans de jeunesse' project have arguably reinvigorated the potential for the medium to cultivate in young audiences a passion for cinema. Bergala's pedagogy aspires to open up opportunities for children not only to 'read' and understand cinema, but also to make cinema themselves. A consistent source of tension throughout The Cinema Hypothesis, however, is what seems to be for Bergala a fundamental incompatibility between film-as-art and school-as-education. Bergala employs a dialectical opposition between cinema and school to conceptualize film education as a voyage of individual experience and/in taste, whose educational goal is cinephilia. While this approach may bode well for the possible role of film in our aesthetic self-education, it arguably does so at the expense of any aesthetic dimension to schooling, and the possibility that our understanding of education might also be transformed and enriched by film-viewing. Further, I would argue that The Cinema Hypothesis provides insufficient justification for why schools have an obligation to play host to this goal. In this paper I intend to examine the four parts that Bergala delimits as appropriate for schools to play in facilitating a film education: (1) setting up the possibility for an encounter with films; (2) appointing, initiating and becoming the passeur; (3) learning to go to the movies; and (4) drawing connections between films. I will suggest that the deliberate staging of an opposition between cinema and the school within each of these roles succeeds in advocating the 
former over the latter, but does not wholly do justice to the ways in which films and schools might be mutually enriching fields of activity and interest.

\section{Film and educational autobiography}

Early on in the articulation of his hypothesis, Bergala (2016: 21) writes that 'Art is by definition a sower of trouble within the institution.' In fact, art's very obligation is to remain 'a catalyst for anarchy, scandal, disorder' (ibid.). This Romantic view of art being the force of wild nature opposed to the rules of law, of institution or normativity is one that was well captured in Jean Vigo's Zero for Conduct (1933) (a film Bergala has used as a reference point within 'Cinéma, cent ans de jeunesse'), in which the innate joyful anarchism of childhood brings down the strict and artificial regulation of the boarding school environment. Vigo's vision was born out of personal experience, and to some extent Bergala also reveals the autobiographical character to his own dialectics in the first chapter of The Cinema Hypothesis. He speaks first of his early encounters with cinema, and the sense that he had been 'saved' from cultural disinheritance by the twin rewards of cinema and schooling (Bergala, 2016: 12). In his own 'novelistic narrative', school saved Bergala from a 'small-town destiny' and also gave him independence from his parents. He goes on to describe how 'cinephilia' then occupied more of his time while at boarding school than his academic studies. Later in life, thanks to a pedagogical experiment conducted at the Centre of Education and Culture in Yerres, Bergala was able to integrate his passion for cinema back into the formal educational environment by devising a curriculum for the practice of teaching cinema studies. One of the conclusions that Bergala arrives at as a consequence of this personal journey is that it is important to effect a turn away from the decoding of cinema as language, or viewing it with suspicion as a vehicle for ideology, and instead 'to consider cinema primarily as an art' (ibid.: 23).

The notion of school and cinema both providing 'access to the adult life and culture that I would later embrace' shows how these poles relate to one another politically in Bergala's thought. Access and encounter are the founding principles of The Cinema Hypothesis, in that everyone should have the right to them, irrespective of what they choose to do with them as a result. Bergala's underlying concern in emphasizing the importance of an early intervention of film in the lives of young people appears to be one of cultural disinheritance - the possibility of being left out. If Bergala says that he was saved by school as much as by cinema (ibid.: 12), it is because he equates the two with the possibility of social and cultural exclusion respectively. Thus far, this is a claim only for access, and has nothing to do with the specific character or value of either film or schools in terms of education, other than that they are sites of participation in a common culture. Neither yet distinguishes itself from other art forms (such as the theatre) or other institutions (such as marriage or the electoral register) in this respect.

Bergala concedes that the mass participation of young people in schooling makes it the only logical site for mass access to the film encounter that is his primary goal. But could one not argue that any attempt to institutionalize art risks killing its spirit completely? Bergala is highly sensible to this concern, and at every stage he leans towards a minimum intervention for the sake of maximum exposure. What allows him to overcome such concerns in order to espouse an institutional introduction to cinema is less a reconciliation with schooling than an admission of defeat: if schools did not provide young people with access to great works, no one would. 'Primary school', writes Bergala 'is not made for such work, but at the same time, for the majority 
of children today, it is the only place where an encounter with art can take place' (ibid.: 22). Schooling is again pictured as the antithesis of art's anarchistic imagination, but necessary to the political ideal of equal opportunity that Bergala has in mind. Herein lies a central, problematic tension within Bergala's dialectics: it is not so much that an opposition between cinema and school should not result in the triumph of cinephilia as a lifelong mode of education; it is more that Bergala remains bound by opposing tendencies towards a Romantic sublime of art as transcendental and intensely individual experience, and education as the architecture of collective egalitarianism and democratic commonality. Towards the end of The Cinema Hypothesis, Bergala reiterates a belief set up by his own experience at the beginning, that 'solitude and risk-taking are at the heart of the act of creation' (ibid.: 115). Without wishing to deny this sentiment outright, I want to suggest here that the romance of solitary aesthetic experience is an inclination towards privacy that is fundamentally at odds with the public orientation of education, not least as articulated in Bergala's own advocacy of equality of opportunity. To explore this unresolved tension in The Cinema Hypothesis further, I will now look at the 'four parts' to the school's role in effecting a film education outlined by Bergala in the text. These four parts are only sketched in rough detail within The Cinema Hypothesis, and therefore some of the criticisms raised here are ones that likely would not have required as much attention had the parts been elaborated further.

\section{Setting up the possibility for an encounter with films}

At numerous stages of The Cinema Hypothesis, Bergala expresses his own hesitations and reservations over the matter of whether film - as art, and as an experience of art can be taught. 'We can require learning, but we cannot require being moved' (Bergala, 2016: 37), he observes when introducing the complex relationships we have with cinema as a highly personal experience. The concern over not being able to require being moved is, of course, true of teaching in most disciplines, and Bergala also recognizes that the situations in which we are moved are more likely to occur independently of the formal learning environment: 'individually, on an intimate scale, each in his own way, even if the encounter took place in what appeared to be a collective context or an institutional setting' (ibid.: 37). The challenge, then, is how to reconcile the intimate experience of individual encounters with film, while also making the case that those should be made possible within the social and socializing context of compulsory education. Might the latter not preclude, or somehow degrade, the former?

Bergala's own response to this question is to affirm the value of the encounter itself, for its own sake, and independently of its aims. Despite the relativist acknowledgement that the 'right conditions' for this encounter 'have often appeared to be the wrong conditions', Bergala then proceeds to take a universal stand for access to the encounter. This ideally would mean 'concretely deploying every apparatus and strategy to place children - the greatest number of children and teenagers - in the presence of films that they will have less and less of a chance of encountering anywhere other than in school' (ibid.: 38). This recommendation rests largely on a democratic educational impulse: good films have the power to transform an individual's perspective on the world, and therefore no one should be deprived of access to that transformation. Whether that transformation actually occurs or not, the possibility should be available to all. The plea is intended to preserve the wide range of individual emotional responses that could arise from the school-based encounter with film, without succumbing to any requirements of learning that schooling so frequently demands as 'evidence' (both in terms of outcomes such as levels of numeracy and literacy, and of socio-behavioural 
skills). While this recommendation is salient in its antagonism of outcome-orientated pedagogies, there are two key aspects it seems to overlook.

Bergala states that no educational situation can require of its students that they be moved by art. In general, it might equally be said that formal education steers away from creating opportunities for emotional or passionate responses to texts and ideas, as they are conducive neither to order - 'teaching is concerned with the rule' (ibid.: 22) - nor assessment. Bergala insists on the opportunity to be moved, but has reservations over the ability of language to do justice to our sense of being moved by art, especially within a formal learning environment: 'You might say, along these lines, that art cannot be taught, but must be encountered, experienced, transmitted by other means than the discourse of mere knowledge, and even sometimes without any discourse at all' (ibid.). When language, education and art are all reduced to a matter of knowledge, all of them lose out. But as Bergala's own autobiography demonstrates, we discover art through context, and something is communicated to us not just through film but in the time and place of the film-viewing. There is a sense in which his own philosophy is informed by the childhood experience of going 'alone, each Sunday afternoon, with total freedom, to see a film of my choosing, about which I kept absolutely silent' (ibid.: 13). The freedom and silence associated with this context reproduce themselves in the private experience that Bergala advocates as film education. The question then arises as to how this private experience can be reconciled with the public orientation of schooling more generally. In wanting to preserve the best of both worlds here, Bergala risks denying their mutual compatibility. If a public, or democratic, education is not just about equality of access, but also about beginning to understand issues of community, then it might be important not just to think of film in terms of cultivating an inner world, but also as a way of relating one's own experience to that of others in the world.

The expression of one's own experience, when it is not governed by outcomespecific rules of classroom teaching, can carry a great risk (see, for example, Munday, 2009). In his essay 'Passionate and performative utterance' (2006), film-philosopher Stanley Cavell speaks of a 'passionate utterance' as that whose direct communication cannot be assured on the path from implication (of the speaker) to desire (of the hearer). This is to say that most of our forms of expression are designed to achieve a particular end or effect in those to whom we communicate them: 'I want you to leave the classroom now', for example, is less an expression of desire than an imperative form that prompts a specific action. In this instance there is little space for confusion as to how we should respond. But there are other forms of expression whose response is less assured, because they have the potential to generate in the listener any number of feelings not guaranteed by the semantics of the phrasing. To say 'I'm bored' in the presence of another person, for instance, gives no indication of an appropriate response; instead, the other person might experience feelings of guilt, anxiety, impatience or sympathy as a result.

Utterances intended to achieve a particular effect are described as 'performative', where 'a performative utterance is an offer of participation in the order of law'. By contrast, a passionate utterance 'is an invitation to improvisation in the disorders of desire' (Cavell, 2006: 185). The parallels with cinema are clear: most people will have encountered films that seem to proceed along the lines of a political or emotional formula, designed to produce a specific effect in the viewer. More complex works, however, will often leave us wondering whether we shared the same experience as others in the cinema. How, then, should an educator respond to this excess, this alienation? In describing this volatility of reception, Cavell would seem to be in sympathy with Bergala's view that the encounter with artworks with no predetermined 
learning objective is important. But the suggested mode of dealing with the sense of private, even isolated, cinematic experience, and where to orient desire, is different. The difference in emphasis is made clear in Bergala's defence of the fragment as pedagogy. He talks about using a clip from Robert Bresson's Au hasard Balthazar (1966) to argue that the child's appreciation of this short scene at the age of 4 is better than that person having to wait until they are 18 to view the whole film. Bergala states that the clip can usefully be contrasted with other short scenes to create 'moments of surprise and amazement' as a way 'to incite desire' for film-viewing that will have more patience for whole films later on (Bergala, 2016: 70). By contrast, for Cavell, the film's entirety is essential to the viewer's ability to take in its themes, and therefore appreciate its claims upon a relation with the world that the viewer occupies, a position of which Bergala himself seems to approve when talking about the film-maker as someone who is '"engaged" by a question, which his film in turn engages' (ibid.: 31). If the film-maker 'is searching and thinking through the very act of making a film' (ibid.), why would we, as viewers, not want to engage with the full question, and not just part of it? Bergala's involvement in projects such as 'Cinéma, cent ans de jeunesse' demonstrates that discussion does indeed sit at the heart of his formulation of cinematic engagement, and yet his reticence on the matter of classroom discussion of (whole) films in The Cinema Hypothesis affirms more of a desire to direct attention towards film as a medium, providing less space for film to be the prompt for conversations around which things in life deserve our attention.

Cavell explores film criticism as a necessary motion in philosophizing, the testing of one's own judgement as a mode of giving shape and form to experience through expression. This comprises an aesthetics of judgement (and therefore an ethics also) that is every bit as educational as the film itself. In this there is potential to create continuity, rather than opposition, between cinema and schooling, because the experience of encountering film is understood and expressed in relation to the surroundings in which it is viewed. The private emotions of excitement, confusion, pleasure and guilt that might arise from watching films in the school context then become part of a conversation that stitches individual experience back into the group encounter, the making public of our understanding that both reshapes our selfawareness in relation to the film and context, and transforms the context also. Criticism, therefore, is what unites art and the institution, because we can only speak of things in the context in which we encounter them, meaning that the encounter will always be defined by context also. To encourage young people to express their experience of film within an educational context means inviting them also to reflect on that context differently, not just as a site of instrumental learning against which we discover art as transcendent, but a place of self-discovery and self-expression in which art plays a role of co-conversationalist.

\section{Appointing, initiating and becoming the passeur}

Conversation may play more of a role in the 'educational adventure' of 'Cinéma, cent ans de jeunesse' (La cinémathèque française, n.d.), but The Cinema Hypothesis firmly situates Bergala's pedagogy more between experience and creation: we learn by viewing, and we learn by doing. These two poles are meant to bypass the possibility that cinema pedagogy might be reduced to discourse, and therefore to preserve the status of cinema as art. But the fear here is less that cinema might be spoken of, and more of the ways in which we speak of it. Bergala is right to be suspicious of those modes of film analysis that want to reduce cinematic expression to something that 
can be 'read' as pure semiotics. This kind of 'language-ism', he says, 'can easily come down to a denial of the reality of cinema as an impure art' (Bergala, 2016: 25). This is echoed in a sentiment of Alain Badiou (2013: 7) about the 'fundamental impurity of cinema' being its greatest virtue. Badiou makes the important point, with which Bergala would presumably sympathize, that technical knowledge should only serve to elucidate our intuition when it comes to film, rather than dictate our taste: 'Knowledge of frame composition techniques should not be something that forces my admiration; rather, I should be able to account in part for the emotion I feel by talking about the composition of frames' (ibid.: 27). The role of the educator, then, might simply be to make available the technical and analytical tools for accounting for emotional responses to films. The figure of the passeur in Bergala, however, seems to attempt more than this role.

The exercise of Cavellian criticism does of course create problems for the passeur, because it suggests that agreement in judgement lies with the whole community deciding what is of importance to them, how any one film speaks to our experience of the world as we currently find it, not as part of an inheritance (of culture, of tradition). Again, Bergala's portrait of the passeur borders on the hesitant when it comes to painting this figure's merits into the picture of education more broadly. Indeed, the charisma of the passeur, much like the force of great art, lies outside the formal educational narrative. Bergala describes the 'messenger' role of the passeur as one that transcends the professional status of the teacher in almost ecstatic terms:

his own symbolic status changes, he abandons for a moment his role as an educator, as that role has been defined and delimited by the institution, in order to take up a way of speaking and interacting with his students that is rooted in a different part of himself, more vulnerable, where his personal tastes come into play, as well as his more intimate relationship to one work of another, where the 'I' that can be so harmful in the role of the teacher becomes practically indispensable to a good initiation (Bergala, 2016: 38-9).

In the abandonment of an educational role, the passeur reinforces a binary distinction between art and life, the filmic and the educational. If the school is reluctantly admitted to be the best site of mass participation in which great art can be encountered by the greatest number of people at the earliest possible age, the teacher, in turn, is seen as a professional role that permits the mystic to initiate others into 'astonishment'. A 'clear awareness of both roles' must be preserved if there is not to be a confusion between 'the rule and exception' (Bergala, 2016: 39). This latter expression is taken from Godard's distinction between culture and art in JLG/JLG (1995), and evinces something of the elitism concealed within the egalitarian project, for it is arguable that the word 'exception' applies less to the work of art (which must ultimately obey some rules of form and genre if we are to accept it as such, however anarchistic) and more to one's own exception from mass culture in the experience of art. The passeur's enforced role as teacher is testament to this exceptionalism, as someone whose personal tastes should not be reducible to the sociocultural function of mere reproduction that is associated with teaching. Such figures are familiar - both in their charisma and their flaws - from films such as The History Boys (2006) and The Prime of Miss Jean Brodie (1969), in which anti-establishment educators such as Hector and Jean Brodie strive to establish educational establishments of their own imagination.

If I am somewhat disappointed by the dim view of the teacher in The Cinema Hypothesis, it is not because I think that all teachers are equally as charismatic as 
Bergala's passeurs; sadly this can never be expected to be the case. But once again, I find the binary distinction between teacher and passeur to be unhelpful in consideration of the possibilities for transformation: teaching should not just rely on a passeur for effective film initiation, but a different relation between film and education could also help to transform what it means to teach. In films such as Half Nelson (2006) and Captain Fantastic (2016), for instance, we find examples of teachers whose passion for an idea of education causes them to overlook the demands that the context of their teaching places on them, not least the demands of individual students. In showing that teaching sometimes means overcoming one's ideology, teaching itself is reaffirmed as something that can be for the good - rather than being the fixed site of ideological or instrumental reproduction from which art is the escape. Can these films therefore not show us how to discover an aesthetics of teaching through film-viewing, rather than seeing the passeur as someone who smuggles aesthetic education in via the teaching profession? Bergala acknowledges that there is a generational gap between the 'teachers who were products of militant cinephilia' and the youth of today 'who have come of age under very different conditions of access' (ibid.: 49). The teacher-student dialogue is important in The Cinema Hypothesis, albeit in a Hegelian configuration that holds that the place for cinema study is one of 'passing down knowledge, convictions, methods, and experiences' (ibid.) between these two generations, and not one of asking how film speaks to the values of today.

\section{Learning to go to the movies}

Bergala's third recommendation for a film education involves 'learning to go to the movies', by which he means not the physical action of going to the cinema, but an attitude towards film that is necessary for its appreciation. This is an attitude, or disposition, of patience and receptivity, a 'long process of impregnation' that again cannot be taught, but only facilitated. If this attitude towards film is to be affirmed, then schooling must be constructed as its near antithesis. The role of the school in the early stages of a person's film education should be 'to facilitate flexible, continuous, lively, individualised access to the film, and to introduce children to a mode of reading that is creative, and not merely analytical or critical' (Bergala, 2016: 39). The school should not 'compete with the laws of entertainment' and must 'accept the otherness of the artistic encounter' (ibid.). On this view, film appreciation is in danger of being perceived as a brood parasite within the school's educational nest, where young cinephiles are reared until they are ready to fly the roost. This negative take on Bergala's celebration of cinephilia as educational goal is intended to draw attention to the problem of film for film's sake, because there is really very little logic in arguing that schools have an obligation to raise people who will fall in love with cinema. To my mind, there is significantly more logic in the view that schools might ideally be places where people fall in love with learning, and that film might play an important role in that process even to the extent that some students will pursue that love of learning through film in later study, while others may carry with them the memory of good schooling via film.

For Bergala, the goal of The Cinema Hypothesis is for film education to be understood as cinephilia. Film is an education in art. I have tried not to reject this argument altogether, because it advances the cause of a wider exposure to films as cultural texts that are worth exploring. But I do not think that Bergala's arguments necessarily point beyond an exposure to film as the development of individual taste and experience in film. What is more, the role of education in film education is reduced to that of a handmaiden to the cinematic sublime. The argument is grounded in a 
more widespread disillusionment with the ability of formal education to do justice to our humanistic, rather than skills-based or outcome-orientated, learning - that we must seek the pleasures of art outside life, rather than see art as part of a conversation with our own lives. This means not only seeing schools as facilitators of film exposure, but also as sites that might be transformed by that exposure.

\section{Drawing connections between films}

The difference between a film-philosophy that has emerged out of the writing of Stanley Cavell and the dialectics of film education as explored in Bergala is that the former says more about the uniqueness of film in its ability to draw connections to other aspects of existence than the latter does in trying to preserve that uniqueness by drawing connections between films. Bergala misses an opportunity to stake his claim for cinematic uniqueness in outlining his four parts for the role of schools in a film education by stating that the primary school classroom is 'the best context in which to approach films as belonging to a chain of artworks' (Bergala, 2016: 40). In saying this, the idea of cultural inheritance is again affirmed, but we lose sight of the specificity of film here, as it becomes part of a broader narrative of cultural heritage that has included a 'fraught network' of other art forms as well: 'Cultural knowledge is nothing more than this ability to relate the painting or film that one is presently seeing, or the book that one is reading, to other paintings, other films, other books' (ibid.: 41). Having denounced knowledge earlier in The Cinema Hypothesis, here it assumes the guise of rite of cultural passage, something from which no young person should be excluded. In this formulation, we see any dynamism peculiar to film fade into the nostalgia of heritage, which Bergala has clearly come to value as a form of inclusion but is inconsistent with any claim to its being an art form that is unique in its educational character.

Without wanting to deny the relationship between film and the other arts (as mentioned above, Alain Badiou (2013) celebrates the impurity of cinema for its capacity to borrow from all the others without completing them), I want to suggest that the educationality of film lies in it being the best medium (better than novels, for example) for making connections back to our own (ordinary) lives, rather than it being seen as part of a chain of extraordinary achievements. For both Badiou and Cavell, the fact that cinema is an art in motion allows, first and foremost, for things 'to become' on screen. For Cavell, this means that we see people, ideas and even objects become transformed by their interaction over the course of a film. In the films of Charlie Chaplin, this 'becoming' is witnessed in the transformation of everyday objects, such as a boot or a pair of forks, into something else entirely (a meal for two or some dancing legs). In a group of Hollywood comedies of the 1930s, Cavell describes how the concept of 'marriage' is transformed from a social institution into something that is constantly negotiated as an intimate conversation between two people. And Cavell shows how in Frank Capra's film Mr Deeds Goes to Town (1936), the title character 'rediscovers philosophy' via his simple questioning of others' intentions (Cavell, in Klevan, 2005: 190). Cavell describes how the peculiar combination of the camera's 'automatic world projections', its ability to draw attention to certain things and not others, as well as the fact of the star (Gary Cooper, James Stewart, Cary Grant, Katherine Hepburn, Irene Dunne) bringing his or her reality to bear on any one role that could not be reducible to that role, create the unique conditions in which this 'becoming' is possible.

Another example of the difference between learning via the arts and learning from film, to which I often refer in my own teaching, is that of Louis Malle's Au revoir 
les enfants (1987). The film follows the autobiographical story of Malle at boarding school during the Second World War, where the Carmelite headmaster hid a group of Jewish boys from the German occupation. The character based on Malle, Julien Quentin, moves from suspicion and rivalry to friendship in his acquaintance with one of the new arrivals, Jean Bonnet, an intimacy that develops through their wellmatched intellectual curiosity. Throughout the film, the boys are seen to trade novels, to play the piano, and to watch films together with varying degrees of interest. Their bonding is dependent upon these activities, but no one of them consecrates their relationship more than the other: there is no sense that one art form is privileged in helping Julien and Jean get the measure of one another. From the viewer's point of view, however, this is a relationship that can only really be understood in motion, via the close-ups of confusion, hostility and recognition that register on the two boys' faces. Where Vigo's boarding school boys were united in their friendly ebullience from the off in Zero for Conduct, Malle's are seen to become friends despite their better instincts, only for Au revoir les enfants to announce their adolescence in one terrible moment. In the film's most poignant scene, Julien accidentally betrays his friend with a glance that could only have been captured by the motion picture, both because of its speed and because of its innocence. The film may be showing throughout that all the arts can foster friendship, but only film as a medium could deliver the sense of the precariousness of this friendship in its context, in which the freewheeling and exploratory gaze of childhood suddenly encounters the perils of following its intuition.

This notion of 'becoming' thus distinguishes cinema from static arts, such as painting and sculpture. Film further distinguishes itself from other arts of movement, such as theatre and dance, in its capacity to draw the viewer's attention deliberately in ways that these other arts cannot. The camera, in this sense, is already instructive in asking us to look at things this way, and not that; it is, in effect, already the passeur. Cavell (1979: 78) endorses this view by celebrating those films that do not affect objectivity (like Godard's), preferring instead films that betray a sense of 'complete conviction, of compassion, of delight or ironic amusement, of longing or scorn or rage or loss'. This is not just a matter of taste, but refers back to Cavell's insistence on criticism as public expression: it is a commitment to taking up a position that can itself be challenged, rather than looking for an objective position of authority. Without the (sincere) subjectivity of the camera, film and viewer cannot properly be engaged in the kind of dialogue that enriches both.

Bergala's film education, then, does not quite do justice to what is educational about film (for example, that it lasts a certain time, over which period it develops certain themes and ideas that can then be captured for contrast and criticism). This is because his primary concern is with cinema, or a love for the cinema, which he believes no one should be deprived of. The value of a passion-driven film education always risks finding itself in a critical cul-de-sac: the circular thesis is that film should be studied so we can understand and identify film. My own response to this problem has been to suggest that maybe we should look to film to educate us in something other than just film. As one final example of what this might look like, I offer the recent documentary, The Wolfpack.

Crystal Moselle's 2015 documentary The Wolfpack follows six brothers who have recently emerged from near total confinement to their flat by a father obsessed with protecting them from the dangers of New York City. The boys have therefore been homeschooled by their mother. At the same time, they have received something of an alternative education via their exposure to cinema, an activity that their oppressive father apparently has not only permitted but endorsed. As such, the films of Scorsese, 
Tarantino and Christopher Nolan were part of their daily diet: not only did they watch the films, but they re-enacted them forensically, word by word, scene by scene.

What is curious about the case of the Angulo brothers is how little they seem to testify to concerns about the negative impact of violent imagery upon young people. They were exposed to the films from a very young age, but no more rejected them than they did take up their representation as a reality. The boys play at being the characters from Reservoir Dogs, but do not confuse Tarantino's world for their own. Their fascination with the films, then, attests to something other than mere entertainment: they act out the films as a way of acting out other personalities, beyond the uniform model that their environment imposes on them (they are not permitted to cut their hair, for example). When we arrive at the end of the documentary, and the boys are starting to make decisions about their futures, they are all choosing to go in very different directions. One of them wants to pursue acting, another wants to go travelling, another just wants to set up home independently (evidence, perhaps, of the power of 'passionate response' to films but also the possibilities that it creates). They are somewhat ordinary, despite their extraordinary incarceration and unusual experience of film.

The Wolfpack provides an interesting contrast with Bergala's Cinema Hypothesis because it observes a completely different relation between film and education. Where Bergala would like film to play a significant role in cultivating aesthetic appreciation among young people, the Angulo brothers show what film as education might really look like. And it is an education in which De Niro's Travis Bickle and Christian Bale's Batman are more real to them than the president of the United States. This is a reality that the boys do not seem ever to have rejected, but to have wholeheartedly embraced. What is more, they have not had a passeur to guide them through this educational process, because the greatest role the father played in the boys' film viewing was simply to permit it. The boys' passion for cinema, then, appears to have occurred independently of the kind of pedagogy Bergala suggests. This cannot be proved, of course, as even the documentary format is edited for narrative effect. But ultimately the question that arises is that, if we do not need to be taught cinema to discover a love for it, what then can be said for the role of cinema in education?

\section{Conclusion: Film as education}

The subtitle to Bergala's book is Teaching cinema in the classroom and beyond; in this paper I have tried to show how cinema might also have something to teach the classroom. If The Cinema Hypothesis represents a sophisticated plea for cinephilia as an educational goal, that is certainly not to the detriment of cinema: a film education according to Bergala's method can only encourage more young people to take an interest in film, both in its appreciation and in its creation. However, there is a sense throughout The Cinema Hypothesis that formal education - the school - exists only in service to cinephilia. The very private character of cinephilia as an educational end means that it remains in opposition to the public orientation of schooling, a contradiction that remains unresolved in the four parts of the school's role set out in Bergala's recommendations for film education. Not only is there something hubristic about this endeavour, but I think it diminishes the special role that film might play in creating (public) conversations about what matters to students, how the things that they see on film play out in, and provide perspectives on, their own lives. Given that a large part of those lives are spent in schools, could it not be valuable also to see film as 
a starting point for conversations around how young people see their education, and how it might be otherwise?

\section{Notes on the contributor}

Alexis Gibbs is Senior Lecturer in Education Studies at the University of Winchester. His primary interests are in educational philosophy and theory, with recent work focusing on what film has to teach the viewer about the nature and character of education. He is the author of Seeing Film as Education (forthcoming, 2019).

\section{References}

Badiou, A. (2013) Cinema. Ed. de Baecque, A. Trans. Spitzer, S. Cambridge: Polity Press. Bergala, A. (2016) The Cinema Hypothesis: Teaching cinema in the classroom and beyond. (FilmmuseumSynemaPublikationen 28). Trans. Whittle, M. Vienna: Austrian Film Museum.

Cavell, S. (1979) The World Viewed: Reflections on the ontology of film. Cambridge, MA: Harvard University Press.

Cavell, S. (2006) 'Passionate and performative utterance'. In Cavell, S. Philosophy the Day after Tomorrow. Cambridge, MA: Belknap Press, 155-91.

La cinémathèque française (n.d.) 'Le Cinéma, cent ans de jeunesse: A cinema education initiative'. Online. www.cinematheque.fr/cinema100ansdejeunesse/en/ (accessed 1 March 2018).

Klevan, A. (2005) 'What becomes of thinking on film?' In Read, R. and Goodenough, J. (eds) Film as Philosophy: Essays on cinema after Wittgenstein and Cavell. London: Palgrave Macmillan.

Munday, I. (2009) 'Passionate utterance and moral education'. Journal of Philosophy of Education, $43(1), 57-74$. 